\title{
Do Eco-rating Schemes Improve the Environmental Performance of Ships?
}

\author{
Poulsen, René Taudal ; Hermann, Roberto Rivas; Smink, Carla K.
}

\author{
Document Version \\ Accepted author manuscript \\ Published in: \\ Marine Policy \\ DOI: \\ 10.1016/j.marpol.2017.10.006 \\ Publication date: \\ 2018 \\ License \\ CC BY-NC-ND
}

Citation for published version (APA):

Poulsen, R. T., Hermann, R. R., \& Smink, C. K. (2018). Do Eco-rating Schemes Improve the Environmental Performance of Ships? Marine Policy, 87, 94-103. https://doi.org/10.1016/j.marpol.2017.10.006

Link to publication in CBS Research Portal

\section{General rights}

Copyright and moral rights for the publications made accessible in the public portal are retained by the authors and/or other copyright owners and it is a condition of accessing publications that users recognise and abide by the legal requirements associated with these rights.

\section{Take down policy}

If you believe that this document breaches copyright please contact us (research.lib@cbs.dk) providing details, and we will remove access to the work immediately and investigate your claim.

Download date: 26. Apr. 2023

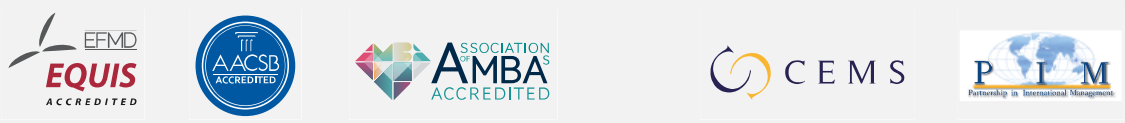




\title{
Do Eco-rating Schemes Improve the Environmental Performance of Ships?
}

\section{René Taudal Poulsen, Roberto Rivas Hermann, and Carla K. Smink}

\author{
Journal article (Accepted manuscript)
}

CITE: Poulsen, R. T., Hermann, R. R., \& Smink, C. K. (2018). Do Eco-rating Schemes Improve the Environmental Performance of Ships? Marine Policy, 87, 94-103. D01:

10.1016/j.marpol.2017.10.006

DOI: 10.1016/j.marpol.2017.10.006

Uploaded to CBS Research Portal: January २०19

(C) 2019. This manuscript version is made available under the CC-BY-NC-ND 4.0 license

http://creativecommons.org/licenses/by-nc-nd/4.0/ 


\title{
Do eco-rating schemes improve the environmental performance of ships?
}

René Taudal Poulsen, Roberto Rivas Hermann and Carla Smink

René Taudal Poulsen, Associate professor, PhD, Department of Innovation and Organizational Economics, Copenhagen Business School, DK-2000 Frederiksberg, Denmark, rtp.ino@cbs.dk

Roberto Rivas Hermann, Post doc, PhD, Department of Innovation and Entrepreneurship, Nord University Business School, NO-8049 Bodø, Norway roberto.r.hermann@nord.no

Carla Smink, Associate professor, PhD, Department of Planning, Aalborg University, DK-9000 Aalborg, carla@plan.aau.dk

\begin{abstract}
This paper examines if eco-rating schemes improve environmental outcomes in the context of the international shipping industry. Shipping faces global environmental challenges and has recently witnessed the introduction of several eco-rating schemes aiming to improve the environmental performance of ships. Extending the private environmental governance literature into a mature service industry with global operations, the paper shows that concerns about eco-rating schemes' effectiveness also have relevance here. Shipping eco-rating schemes fall short of best practices for design and governance, and this hampers improvement efforts. The study has policy implications for the achievement of improved environmental outcomes in the shipping industry.
\end{abstract}

Keywords: Eco-rating schemes; Shipping industry; Private environmental governance; Corporate environmental disclosure

\section{Introduction}

The environmental footprint of the international shipping industry is a source of increasing global concern. It includes challenges such as oil spills, toxic hull paints, and waste and garbage handling, which have been subject to international policy discussions since at least the 1960s [1]. Within the last two decades, several other challenges, including global climate changes [2,3], air pollution [4-8], invasive species [9-13], underwater noise [14], recycling [15], and interactions with marine mammals [16] have entered the environmental protection agenda of the industry. While shipping shares most challenges with onshore industries (such as other transportation modes, power plants, and manufacturing), it has generally addressed them relatively late [17]. Moreover, forecasts indicate that $\mathrm{CO}_{2}$ emissions and air pollutants such as nitrogen oxides $\left(\mathrm{NO}_{\mathrm{x}}\right)$ and particulate matter (PM) are likely to rise in the coming decades [2], and studies have called for further action to decarbonize the industry [18-20]. Accordingly, the circumstances under which improved environmental outcomes can occur in shipping receive increasing attention from maritime and environmental governance scholars $[17,21-31,110]$, and the question remains unresolved.

Since the early 2000s, shipping has witnessed the emergence of several eco-rating schemes aiming for improvements of the environmental performance of ships. The schemes are designed to provide 
environmental guidance for several industry stakeholders and incentivize improvement efforts. As presented to the Sustainable Shipping Initiative (SSI), a shipping NGO,

"Most rating schemes are designed to enable comparison between ships, services or fleets, to allow business customers to select and reward best performers, and for ship owners/operators to differentiate themselves in the market. Other schemes have linked up with ports and offer benefits, such as reduced port fees." [32]

The shipping industry is a relatively late adopter of schemes which provide environmental performance information to the market place [27]. Fisheries and forestry were among the first to do so around 1990, when the MSC and FSC labels were introduced [33, 34], and several industries have followed suit [35, 36]. Extensive numbers of private environmental governance articles have discussed the extent to which eco-ratings and eco-labelling contribute to improved environmental outcomes, i.e. their environmental effectiveness [37-39]. Ideally, they provide environmental benchmarking tools to buyers, who can make informed decisions and acknowledge the environmental footprint of a particular product or service. Sellers can differentiate their products, gain market shares, and create new markets based on high environmental performance. However, several studies have questioned consumers' willingness to pay for eco-rated or eco-labeled products if prices exceed the average [40]. Likewise, scholars have argued that corporations might use ecorating schemes to deflect regulation or provide confusing or irrelevant information to the market place [38], or squeeze out small competitors, who might not be able to gather sufficient data to qualify for inclusion in the schemes [44, 45]. Some scholars argue for a need for regulation of schemes in order to ensure improved environmental outcomes [41].

Most research has been directed towards sectors with early adoption of eco-rating and eco-labelling schemes, such as extractive and consumer goods industries. In the context of shipping, the question of eco-rating schemes' environmental effectiveness has not been thoroughly examined, even though the industry faces global environmental challenges and has seen several eco-rating schemes emerge in recent years. This paper extends the discussion on eco-ratings' effectiveness into the context of the international shipping industry, investigating the following research question:

Do eco-rating schemes improve the environmental performance of ships?

Environmental performance refers to any aspect of a ship's environmental footprint. A performance improvement - here also referred to as better environmental outcomes - occurs whenever an aspect of a ship's environmental footprint is reduced. For instance, a reduction in a ship's $\mathrm{CO}_{2}$ emissions relative to the transport work it performs will represent a performance improvement. Transport work is usually measured in ton-miles, and reflects the volumes of cargoes carried and the distances travelled per year [42]. Likewise, reduced underwater noise levels or more effective ship recycling methods will represent improvements in the environmental performance of ships. Industry level improvements, on the other hand, will depend on the global demand for shipping services. Despite improvements in the environmental performance of individual ships, rapid growth in the demand for shipping service can cause an increase in the world fleet and translate into a higher environmental footprint from the industry at large. In the following analysis, the discussion is focused on the environmental effects of eco-ratings on the ship level only. 
The paper sheds new light on the circumstances under which improved environmental outcomes can be expected to occur on the ship-level. In studying shipping, the paper extends the private environmental governance literature into a mature service industry with global operations. Beyond the retail service industry [40], service industries have generally not received as much attention as the extractive sector. They deserve further studies, and shipping is a particularly interesting service industry due to its global operations and environmental footprint. In terms of technology, shipping is a mature industry. The main ship types and designs have existed since the 1960s, and technological developments have largely been incremental in the same period [42, 43].

The paper is structured as follows: First, it presents a literature review on the best practices for the design and governance of eco-ratings, as well as literature on environmental disclosure in shipping. Then it presents the methods and data. In section four, shipping eco-rating schemes are analyzed and assessed in the light of the best practices from other industries, and section five discusses the findings. In conclusion, section six presents the implications of the study.

\section{Literature review}

\subsection{Best practices for eco-rating schemes}

Numerous private environmental governance articles have examined eco-rating and eco-label schemes, which provide information on the environmental performance of a product or service to the market place. Discussions concern the environmental effectiveness of the schemes: Do the schemes achieve improved environmental outcomes or fail in their promises? For instance, with reference to the Marine Stewardship Council's MSC label, Ponte [44 p. 171] argued that, it "...is not simply a non-political, neutral, and scientific tool against over-fishing... It is achieved in the context of global and local competition, special interest battles, and local politics." Auld et al. [45] have argued that the stakeholders' motivations for engagement with eco-ratings and eco-labels can indicate environmental effectiveness (or lack of such). Motivations can range from the creation of market differentiators or new markets, to policy deflection and deliberate information overload in the market place. In the first two cases, improved environmental outcomes are more likely to occur than in the latter two. Therefore, it is important to study the motivation for engagement among stakeholders, and this paper follows suit below.

A recent study by Baumeister and Onkila [46], on the potential for ecolabels in aviation, is particularly relevant because aviation and shipping share key characteristics as service industries with global operations. Baumeister and Onkila [46] argued that a number of design and governance dimensions are critical to the success of such a scheme. The paper follows their call and investigates both design and governance dimensions. After two decades of research, some best practices for the governance and design of eco-rating schemes have crystalized from the literature (Table 1). With regard to the design dimension, the ideal is universality in the form a global recognition of only one scheme for a specific environmental challenge. If several schemes with partly overlapping aims exist (e.g., two or three schemes focused on air pollution), buyers will have difficulty distinguishing between the benefits of each, and sellers will face the same confusing situation [47]. Competition between schemes for members or users might water down entry criteria and reduce environmental effectiveness $[38,47]$. The literature also emphasizes transparency regarding the environmental footprint, which requires data for benchmarking of environmental performance of different products or services $[37,39,48]$. With regard to scheme governance, credibility is crucial. Data 
should be verified by a professional third party [37-39, 47, 49]. Finally, engagement from all relevant stakeholders is critical for legitimacy $[37,44]$. This also includes civil society participation in the scheme [50].

Table 1. Best practices for ecolabels

\begin{tabular}{|l|l|l|l|}
\hline Dimension & Criteria & An ecolabel shall... & Key references \\
\hline \multirow{4}{*}{ Design } & \multirow{2}{*}{ Universality } & $\begin{array}{l}\text { avoid overlaps with other } \\
\text { ecoratings }\end{array}$ & {$[38,47]$} \\
\cline { 2 - 5 } & & $\begin{array}{l}\text { allow for environmental } \\
\text { benchmarking of a product or } \\
\text { service }\end{array}$ & {$[37,39,48]$} \\
\hline \multirow{3}{*}{ Governance } & Transparency & $\begin{array}{l}\text { enjoy widespread stakeholder } \\
\text { support }\end{array}$ & {$[37,44,50]$} \\
\cline { 2 - 5 } & Legitimacy & $\begin{array}{l}\text { be subject to third party data } \\
\text { verification }\end{array}$ & {$[37-39,47,49]$} \\
\hline
\end{tabular}

\subsection{Literature on corporate environmental disclosure in shipping}

While the question of eco-ratings' environmental efficiency has not been directly addressed in shipping industry studies, a number of articles have addressed questions pertaining to corporate environmental disclosure more broadly and environmental strategies of shipping companies. Lai et al. [22 p. 631] defined Green Shipping Practices (GSPs) as "environmental management practices undertaken by shipping firms with an emphasis on waste reduction and resource conservation in handling and distributing cargoes" and suggested a positive relationship between such practices and shipping company competitiveness. In contrast, van Leeuwen and van Koppen [51] concluded that shipping companies predominantly employ "crisis-oriented" environmental strategies, in which compliance represents the highest ambition. Rahim et al. [28] followed this line of reasoning in a critique of corporate disclosure practices for $\mathrm{CO}_{2}$ emissions among the eight largest container lines. They concluded that emission reductions can be achieved, if shipping companies are required by law to disclose information on their $\mathrm{CO}_{2}$ performance. In the following, it is examined if shipping companies use environmental information to differentiate their services, in order to understand if shipping companies see environmental performance as a potential source of competitive advantage.

In 2012, Wuisan et al. [23] published a case study of the Clean Shipping Project (CSP), which has developed the Clean Shipping Index (CSI), an eco-rating scheme. While still in an early stage of development, the CSP had a "promising" outlook. Since environmental regulation in shipping was "not sufficient to uncouple growth in shipping from environmental harm" (p. 171), the CSP was a "welcome initiative", which could contribute to environmental improvements. Wuisan et al. suggested that the project should broaden the collaboration and include ports and investors as members. They also advised alignment with regulation from the International Maritime Organization (IMO) and the European Union (EU) in order to avoid conflicts and unnecessary overlaps. Below, the paper examines if alignment has been achieved and if ports and investors have joined in the five years after the publication of Wuisan et al.'s study. 
A few studies have focused on the role of shippers or cargo-owners in the greening of shipping. In a survey study, McKinnon examined shippers' influence on carbon emissions from container shipping, and concluded that "Very little consideration is currently given to differences in environmental performance in the selection of deep-sea carriers, despite the fact that benchmark data is now available on the carbon intensity of particular container services on specific trade lanes" [25 p. 17]. Poulsen et al. [27] documented significant segment differences with regard to shippers' environmental expectations. In container shipping, cargo-owners increasingly ask carriers questions regarding $\mathrm{CO}_{2}$ emissions, while cargo-owners in other segments only focus on oil spill prevention (tankers), or show very little interest in environmental performance (dry bulk). They concluded that (p. 57) "...environmental upgrading in shipping is not likely to materialize without clear and enforceable global regulation and stronger alignment between regulation and voluntary sustainability initiatives." Finally, Schniederjans and Starkey [52] examined factors which influence end-consumers' willingness to pay for 'green' transport of T-shirts, concluding that organizations and governments should improve the conditions for the marketing of green transportation.

In the maritime energy efficiency literature, corporate environmental disclosure has also been addressed. Studies have examined questions pertaining to data on ships' fuel consumption, which is linearly related to $\mathrm{CO}_{2}$ emissions. Agnolucci et al. [53] and Adland et al. [54] asked if energy efficient Panamax dry bulk carriers receive a premium in the time-charter market, and concluded that the financial savings from energy efficiency do not fully accrue to ship owners. This reduces the shipowners' incentives to invest in energy savings and hampers emission reduction efforts. In booming freight markets, Adland et al. [54] showed that even fuel-inefficient ships (i.e. vessels with high levels of $\mathrm{CO}_{2}$ emissions per transport-work) attract a premium. The two articles pointed towards a lack of data on fuel consumption as a possible explanation for these counterintuitive findings. If fuel savings are difficult to verify and inadequate information is available, charterers are reluctant to pay a premium. This explanation aligns with conclusions reached by Poulsen and Johnson [55] in a study on energy efficiency in ship operations. They documented widespread challenges with the collection and analyses of fuel consumption data, and confirmed that lack of energy efficiency information within shipping organizations and in shipping markets lead to unnecessary fuel consumption and emissions. Ideally, eco-rating schemes could provide such information, guiding energy efficiency investments and leading to improved environmental outcomes. This is investigated below.

\section{Methods}

Any study examining a causal link between eco-ratings and environmental outcomes faces the methodological challenge of separating the effects of the schemes from those of other factors. In cases where improved environmental outcomes occur, they may be attributed to other factors than eco-ratings (e.g., new regulation or innovation). In industries with a relatively short experience with eco-ratings, such as shipping, any positive environmental effect must be of a very recent date. However, from studies in other sectors, best practices for schemes (as described in section 2) have crystalized, and these can be applied to the study of shipping schemes. If shipping schemes fail to follow the best practices, their environmental effectiveness is likely to be reduced.

A total of six eco-rating schemes, identified from the SSI's website list of shipping eco-ratings, are assessed [56]. The data sets come from the schemes' websites as well as articles published in a global shipping newspaper, Lloyd's List. The websites are used to illuminate both design and 
governance dimensions of each scheme. On the design dimension, the questions of how environmental performance is measured and benchmarked (the question of transparency), and whether overlaps between eco-ratings exist (the question of universality) are key. On the governance dimension (i.e. the questions of legitimacy and credibility), the main stakeholders, as well as possible third party data verifiers, are identified. The scheme websites do not reveal potential hidden agendas among participants, but relevant stakeholders, who are missing from the member lists, can be identified.

While the web pages provide valuable information on design and governance dimensions, they do not allow a full answer to the question of legitimacy, including stakeholder motivation for participation. However, articles from the electronic archives of Lloyd's List for the period January 1 , 1990 - September 14, 2017, shed light on this question. The following search words have been used to identify relevant articles: Environmental Ship Index/ESI, Clean Cargo Working Group/CCWG, Existing Vessel Design Index/EVDI/Rightship/Shippingefficiency.org, Clean Shipping Index/CSI, Green Award, BetterFleet and Monitoring Reporting and Verification/MRV.

Since new regulations from the $\mathrm{EU}$ and IMO concerning standards for corporate disclosure of $\mathrm{CO}_{2}$ emissions, so-called Monitoring, Reporting and Verification (MRV) (as will be discussed in Section 4.3) will soon enter into force, the web pages of the two organizations were also investigated. MRV and eco-rating scheme requirements are examined (the question of transparency), in order to assess if they align.

\section{Analysis}

\subsection{Design}

\subsubsection{Universality}

Ideally, only one eco-rating scheme with global recognition addresses a specific environmental challenge, and any overlaps with other schemes are avoided. In shipping, however, such universality has not been achieved. At least six shipping schemes hold a global ambition, with overlapping measurements of environmental performance: Environmental Ship Index (ESI), Clean Cargo Working Group (CCWG), Clean Shipping Index (CSI), Green Award, Existing Vessel Design Index (EVDI, from Rightship/Shippingefficiency.org) and BetterFleet (also from Shippingefficiency.org). Providing environmental guidance to cargo-owners/charterers, shipping companies, port authorities, financiers and other stakeholders, these eco-rating schemes have developed partly competing environmental benchmarking methodologies. They are all concerned with $\mathrm{CO}_{2}$ emissions, and some of the schemes also have different methodologies for measurements of air pollutants.

Recently, the CSI and CCWG investigated the possibility of establishing "one global initiative". Both boards have come "...together on numerous occasions, though have not reached resolution on key points" [57 p. 8]. The reason for this divergence, and the existence of six schemes, is related to the different stakeholders, who have only partly overlapping aims. The lack of universality forces all stakeholders to select between schemes, and this is likely to reduce environmental effectiveness.

\subsubsection{Transparency}


Measuring the environmental footprint of a ship is a challenge for all schemes. Some environmental challenges are related to fuel consumption and others are not. Largely, shipping schemes focus on fuel consumption and air emissions. In 2011, Rightship, a vetting company owned by three major dry bulk cargo-owners, and Shippingefficiency.org, an NGO associated with the Carbon War Room, jointly introduced the Existing Vessel Design Index (EVDI) to compare "a ship's theoretical $\mathrm{CO}_{2}$ emissions relative to peer vessels of a similar size and type using an easy to interpret A-G scale" [58]. It is calculated based on principles, which were developed by IMO for the Energy Efficiency Design Index (EEDI). EEDI specifies a minimum energy efficiency level for all new ships in design condition delivered since 2013 [59]. EVDI applies the same calculation principles to all vessels, and is based on data from various sources, including classification societies, engine manufacturers, IMO publications, and ship-owners. Data verified by classification societies is seen as the best quality data [58]. EVDI rating data sets for the entire world fleet (except passenger ships) are freely available on the shippingefficiency.org web page, and more detailed data sets are available for Rightship's paying members. Given the theoretical nature of the calculation of ships in design condition, the EVDI does not provide full transparency regarding ships' actual energy efficiency and $\mathrm{CO}_{2}$ emissions. Fuel consumption depends on vessel operational performance, which can vary significantly [55].

Some of the shortcomings of EVDI will be rectified by a new eco-rating scheme, BetterFleet, which was launched on the website of Shippingefficiency.org in November 2016. It is still under development according to the website, and has not replaced the EVDI [112]. Using satellite data for tracking of ship movements and an advanced computer model, BetterFleet estimates individual ship's $\mathrm{CO} 2$ emissions per ton-mile in the last twelve months. It compares ships of the same types and sizes. On this basis each ship receives a score on a 1-10 scale, which will be freely available on the website. This methodology promises to enhance transparency regarding individual ship's $\mathrm{CO} 2$ performance [111].

The CCWG also focuses on $\mathrm{CO}_{2}$ emissions, but is limited to container shipping. In container shipping, environmental benchmarking is particularly challenging because of container lines' widespread use of third party feeder services, vessel sharing agreements, and the repositioning of empty containers [60]. The CCWG has developed a methodology to benchmark $\mathrm{CO}_{2}$ performance for carriers on specific trade lanes (e.g., Asia - Northern Europe) and individual ships in the same trade lanes. Transparency with regard to $\mathrm{CO}_{2}$ performance for ships and companies is high, but data sets are only available for CCWG members.

The CSI is also a "cargo owner driven" scheme [61 p. 3] and aims to develop into a "ticket to trade" [61 p. 3]. It is not limited to a particular shipping segment. Ships and companies are rated on five steps based on their performance on five environmental issues - including $\mathrm{CO}_{2}$, air pollution (Sulphur Oxides $\left(\mathrm{SO}_{\mathrm{x}}\right), \mathrm{PM}$ and $\mathrm{NO}_{\mathrm{x}}$ ), use of chemicals, and waste handling [62]. CSI has the broadest definition of environmental performance among the eco-ratings, and provides a relatively high level of transparency for environmental benchmarking, but only for its paying members. It also accepts CCWG $\mathrm{CO}_{2}$ methodology for container ships.

Two schemes have been developed by the port sector: The ESI from the World Port Climate Initiative (WPCI) and the Green Award from the Green Award Foundation. The ESI was initiated by a group of port authorities in 2008, mainly due to concerns about local air pollution, which can threaten ports' social licenses to operate. They have developed ESI to incentivize air pollution abatement from ships 
in ports [63]. ESI scores are mainly based on air pollution reduction ( $\mathrm{SO}_{\mathrm{x}}, \mathrm{NO}_{\mathrm{x}}$ and $\mathrm{PM}$ emissions). Ships with scrubbers or other exhaust gas cleaning devices, or onshore power systems installed, achieve high scores. Scores, however, are granted regardless of the operation of these exhaust gas cleaning devices [64]. In other words, the ESI does not allow for benchmarking of ships' operational performance.

Established by the Port of Rotterdam and the Dutch Ministry of Transport in 1994, the Green Award is by far the oldest shipping scheme. It was developed at a time when oil spills were a major public concern, in order to incentivize improvements in ship safety, mainly for tankers. It became an independent organization in 2000, and earns revenue from certification of tankers and bulk carriers - or in its own words, it "certifies ships that are extra clean and extra safe."[65]. Originally focused on safety and oil spill prevention, the original Green Award certificates concerned vessel maintenance, crew training, and safety procedures - or in the words of Lloyd's List, the aim was to "make supertanker owners more environmentally aware" [66]. More recently, the Green Award audit also included questions on shipping company measures to reduce air pollution and $\mathrm{CO}_{2}$ emissions, and shipbreaking policies [67]. The certification scheme, however, is not a tool for environmental benchmarking of ships, which either receive a certificate or fail. A list of certified vessels is published on the foundation's web page [68]. Therefore, it does not provide high transparency to the market place on individual ships' environmental performance.

Different definitions of environmental performance challenge efforts for environmental improvements (For ratings of four selected vessels please see Table 2). While air pollutants are the focus of port initiatives, cargo owners are largely focused on $\mathrm{CO}_{2}$ (with the exception of CSI). Both challenges are related to ships' fuel consumption, but solutions do not come simultaneously. Scrubbers for $\mathrm{SO}_{x}$ reduction and $\mathrm{NO}_{x}$ abatement technologies achieve high scores in the ESI; however, they consume fuel and increase $\mathrm{CO}_{2}$ emissions. Onshore power systems, which are also incentivized by ESI, allow ships to plug into onshore electricity grids while at berth and reduce local air pollution. Their climate effects, however, depend on electric power sources. Finally, LNG as marine fuel, which is incentivized by port schemes, reduces air pollution; but in the best case, $\mathrm{CO}_{2}$ emissions are reduced by only a marginal percentage [69]. 
Table 2. Eco-ratings of four selected vessels, October 2, 2017 (Sources: Web pages of the eco-rating schemes).

\begin{tabular}{|c|c|c|c|c|}
\hline Name of vessel & BW Lioness & Gijon Knutsen & Maran Arete & Kazimah III \\
\hline IMO number & 9675509 & 9313527 & 9776547 & 9329693 \\
\hline Ship type & Chemical tanker & Shuttle tanker & $\begin{array}{r}\text { Very large crude } \\
\text { carrier }\end{array}$ & $\begin{array}{r}\text { Very large crude } \\
\text { carrier }\end{array}$ \\
\hline DWT & 49,999 & 35,144 & 319,398 & 317,250 \\
\hline Built & 2014 & 2006 & 2016 & 2006 \\
\hline $\begin{array}{l}\text { ESI score (on a scale } \\
\text { from } 0 \text { to } 100 \text { ) }\end{array}$ & 47,5 & 0 & Not rated & 36,1 \\
\hline $\begin{array}{l}\text { BetterFleet score (on a } \\
\text { scale from } 1 \text { to } 10 \text { ) }\end{array}$ & 8 & 8 & Not rated & 4 \\
\hline $\begin{array}{l}\text { Green Award } \\
\text { certification }\end{array}$ & Not certified & Certified & Certified & Certified \\
\hline $\begin{array}{l}\text { EVDI score (on a scale } \\
\text { from } G \text { to } A \text { ) }\end{array}$ & 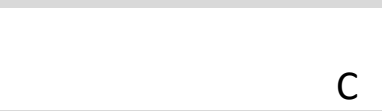 & $\mathrm{F}$ & G & 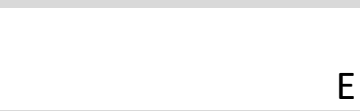 \\
\hline CCWG score & $\begin{array}{r}\text { Only container ships } \\
\text { are rated }\end{array}$ & $\begin{array}{r}\text { Only container ships } \\
\text { are rated }\end{array}$ & $\begin{array}{r}\text { Only container ships } \\
\text { are rated }\end{array}$ & $\begin{array}{r}\text { Only container ships } \\
\text { are rated }\end{array}$ \\
\hline $\begin{array}{l}\text { CSI score (on a five step } \\
\text { scale) }\end{array}$ & $\begin{array}{l}\text { Unknown (no data } \\
\text { publicly available) }\end{array}$ & $\begin{array}{l}\text { Unknown (no data } \\
\text { publicly available) }\end{array}$ & $\begin{array}{l}\text { Unknown (no data } \\
\text { publicly available) }\end{array}$ & $\begin{array}{l}\text { Unknown (no data } \\
\text { publicly available) }\end{array}$ \\
\hline
\end{tabular}


The environmental footprint of shipping is broad, and eco-rating schemes largely ignore the challenges beyond air emissions. Ballast water management addressing invasive species has only been included in CSI scores, but with the entry into force of the IMO Ballast Water Management Convention, CSI has dropped it [62]. While highly debated within the pages of Lloyd's List, the question of ballast water management is therefore left entirely in the hands of policy makers [70, 71]. Invasive species are also spread with hull bio-fouling, which is currently not addressed [17]. Other environmental challenges, such as underwater noise and accidental interactions with marine mammals, are neglected by all shipping schemes. Likewise, the environmental footprint associated with the end of life-cycle of ships is neglected. An estimated $85 \%$ of the world fleet is recycled on beaches in Bangladesh, India, or Pakistan, involving significant environmental challenges related to the handling of hazardous materials [72]. The IMO has developed the Hong Kong Convention to address these challenges, but it has not entered into force [73]. CSI specifically mentions recycling, but it does not include it in the calculation of scores [62]. For the eco-ratings, the life-cycle perspective is complex. The decision on where and how to recycle a ship is often taken by other owners than the current ones, since ships often change hands during their life-cycle [74].

\subsection{Governance}

\subsubsection{Credibility}

CSI's data sets are fully subjected to third party verification by classification societies (CSI 2017). In some cases, CCWG members' data are also verified by third parties, but members are also allowed to submit data which has not been verified in this way [57]. ESI data sets are based on ship-owner self-assessment, although the WPCI holds the right to audit data [75]. The credibility for EVDI is questionable, since data sets are derived from many sources, some of which are not third party verified [58]. It is possible for ship-owners to provide feedback to Shippingefficiency.org regarding the EVDI rating for their individual vessels. For instance, ship-owners can report to Shippingefficiency.org on retrofits and request an update of their ratings.

BetterFleet is entirely based on publicly available data, and the main source is satellite data (AIS data) on individual ships' movements, service speeds, draughts (reflecting the weight of cargoes carried) and distances travelled. These data generally have a high credibility, although local sea and weather conditions, which influence ship's fuel consumption, are only covered with proxy weather data. Anomalies from the data sets are removed by a commercial provider of satellite data, exactEarth, thus enhancing credibility [111].

Finally, the Green Award foundation certifies ships, based on audits onboard and in shipping company offices every three years [76], which means that the certificates have high credibility. Green Award is the only shipping scheme which certifies shipping company management procedures. However, Green Award only indicates whether a ship is certified or not, and names of ships, which have failed to achieve a certificate, are not made public.

Accreditation agencies such as ISO have set best practice criteria for eco-rating schemes, and evaluate and accredit schemes in order to improve transparency [108]. This, however, is not the case for any of the shipping eco-rating schemes.

\subsubsection{Legitimacy}


Since 2010, the CCWG has aimed for and succeeded in gaining increasing support for its $\mathrm{CO}_{2}$ emission benchmarking methodology in container shipping. Approximately $85 \%$ of global ocean container capacity is represented by the CCWG, and 22 large branded cargo-owners and freight forwarders were CCWG members in 2016. While 22 is a low number compared to the total number container shipping buyers, the container volumes of these cargo-owners are large. CCWG gathers data for approximately 3,300 container ships [57] out of world total of 5,200 [77].

EVDI data for almost the entire world fleet are publicly available on shippingefficiency.org, free of charge, and the EVDI thus has the broadest coverage of any of the six schemes. In April 2016, "39 charterers representing $20 \%$ of global trade, factor energy efficiency into their decision-making through RightShip's GHG Emissions Rating" and 12 ship-owners "utilize the GHG rating to demonstrate the benefits of investing in efficiency" [58]. Twelve ship-owners represent a miniscule share of the global ship-owner community, and it is unclear how much weight the 39 charterers put on the EVDI for their procurement decisions. It is clear, however, that the EVDI has received considerable attention in the pages of Lloyd's List, where ship-owner skepticism is very pronounced [78-82]. Concerning EVDI, Rob Lomas, Secretary-general of Intercargo, an international ship-owner association, was quoted as follows:

"What we do not want is yet another simplistic and inaccurate rating system which fails to take into account the progress made at IMO and which merely loads additional costs into the entire supply chain for no conceivable environmental benefit." [80]

BetterFleet, launched by Shippingefficiency in November 2018, is still under development. Like EVDI it will make data freely available for the world fleet, but it is too early to assess its diffusion in shipping. So far, it has only received one brief mention in the pages of Lloyd's List.

Established in Sweden in 2008, with public support, CSI largely remains a Swedish initiative. All board and technical committee members are Swedish, and the cargo-owner members, who pay an annual fee for membership, are to a large extent based in Sweden [83]. There is no indication of NGO participation. In Lloyd's List, CSI has attracted very little attention - for a few exceptions see [84-87]and was only mentioned once since June of 2014 [88]. The current number of vessels included in CSI is not available on the label web page, but in 2013, approximately 2,000 vessels were included [56]. This evidence suggests only modest diffusion in the industry. While fulfilling the transparency and credibility criteria, the CSI has not achieved broad legitimacy.

In the case of ESI, a total of 50 organizations use the eco-rating to provide incentives to shipping companies in the form of reduced port and fairway dues [89]. Although some major ports and the Panama Canal are incentive providers, the ESI does not enjoy wide support in the port sector. As of April 1, 2017, 5,500 ships out of the world fleet of more than 49,000 vessels (of 1,000 GT or above) were enrolled in the ESI, and data are available on the WPCI web page [90]. ESI was only mentioned three times - in brief - on Lloyd's List since May 2014, indicating that most ship-owners do not generally show much interest in the scheme [91-93].

In the case of Green Award, certified ships are granted reduced port fees by 34 port authorities around the world, and the total number of certified ships stood at 248 in July 2017 [68], and in 2010, the number was 234 [94]. Green Award incentive providers and certified ships represent only a minor share of the port sector and the world fleet, respectively. 
While the schemes argue that they can be used by shipping companies for service differentiation $[83,95]$, evidence for such is absent within the pages of Lloyd's List, where EVDI is portrayed as "controversial", and CCWG, CSI, ESI, and Green Award receive only little attention. Most recently, the number of articles on eco-ratings has declined in Lloyd's List, suggesting a generally low interest in the global ship-owner community (Figure1). Moreover, shipping companies still appear to be reluctant with regard to costly investments in exhaust gas cleaning, cleaner marine fuels, and energy efficiency [96]. Even in consumer-facing niches in ferry and cruise shipping [42], no evidence suggests that shipping companies use eco-ratings for service differentiation. Passenger shipping companies are not mentioned on eco-rating scheme member lists or in eco-rating articles in Lloyd's List. In a recent article in the newspaper, it was even argued by an environmental NGO that "Cruise ships fare poorly in pollution rankings" [109].

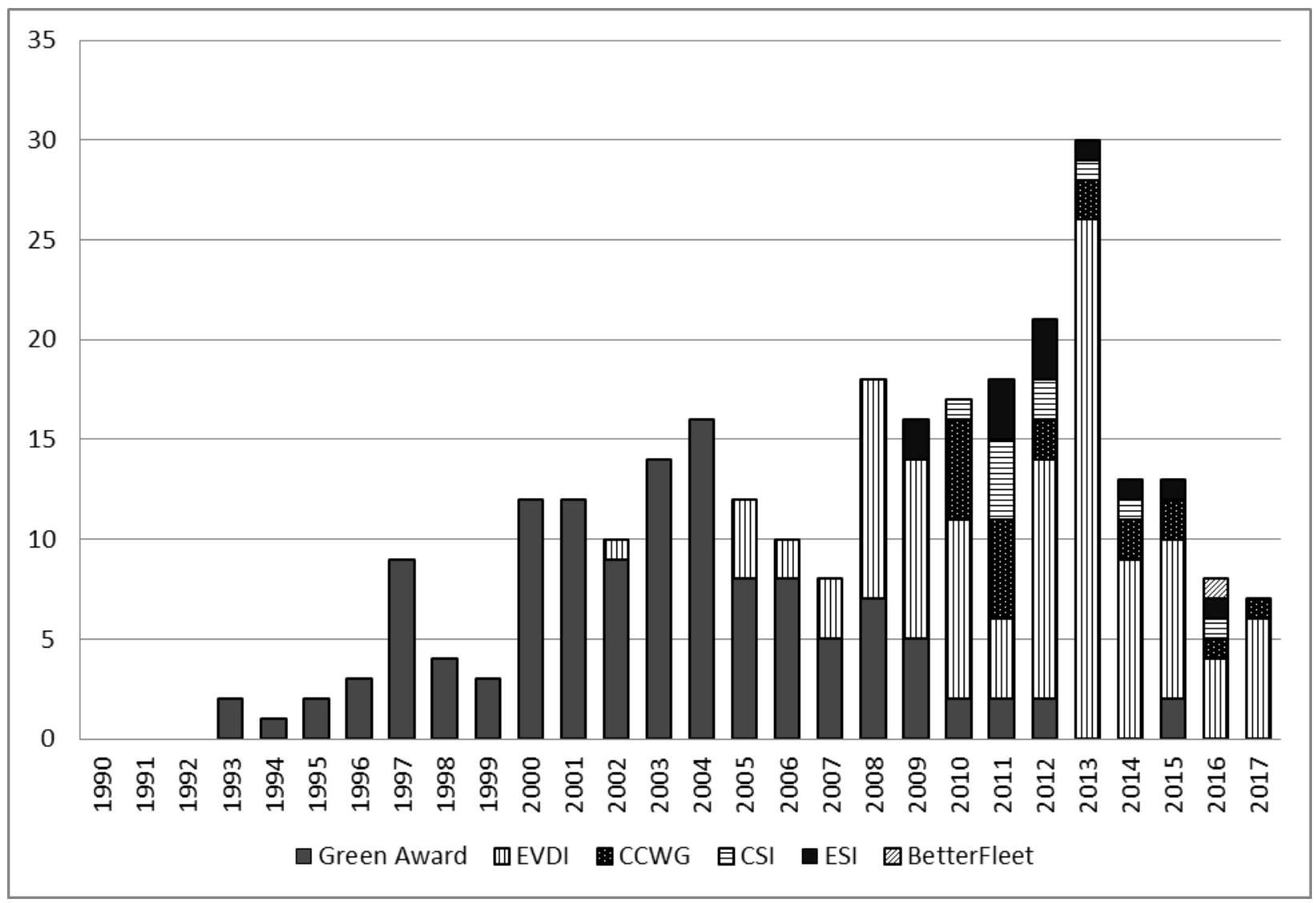

Figure 1. Annual number of mentions of eco-rating schemes in Lloyd's List, 1990-2017.

Note: Data for 2017 covers the period January 1-September 14 only.

The private environmental governance literature suggests that broad stakeholder participation is critical for schemes' environmental effectiveness. In shipping, the two key stakeholders, ports and cargo-owners, engage in eco-ratings for different reasons - concern about local air quality and global climate changes, respectively - and pull in different directions. This is likely to reduce the effectiveness of the schemes. It is notable that other stakeholders are largely absent from eco-rating discussions. Financiers, only mentioned by Rightship/Shippingefficiency.org, and CSI [97, 98], are crucial in this capital intensive industry, but do not appear to play any significant role in the development and use of eco-ratings. On January 25, 2016, an article with the title "Anthony Veder 
secures first certified 'sustainable' shipping loan", was published in Lloyd's List [88]. It explained how the design of a new ship for Anthony Veder, a shipping company, was evaluated by a bank according to the CSI, before a loan was granted. The event was so rare that it deserved mentioning in the shipping press. Eco-ratings could guide investments (for instance identifying energy-efficient ships), but this does not seem to be the case at the moment. CSI, CCWG, and ESI do not have financiers as members. Likewise, environmental NGOs are remarkably absent from the schemes' member lists, suggesting that shipping schemes have not achieved broad legitimacy among stakeholders. Low legitimacy is likely to reduce environmental effectiveness.

\subsection{Regulation corporate environmental disclosure}

Despite the existence of eco-ratings, the $\mathrm{EU}$ and IMO are introducing new regulations requiring shipping company $\mathrm{CO}_{2}$ disclosure, so-called Monitoring, Reporting, and Verification schemes (MRV). Aimed at enhancing environmental transparency, the MRVs require shipping companies to improve their collection of data on fuel consumption and provide more information to the public on their $\mathrm{CO}_{2}$ emissions. The EU scheme is the more ambitious of the two, and will apply to all ships calling at EU ports beginning in 2018. It requires collection of ship fuel consumption data (and therefore $\mathrm{CO}_{2}$ emissions) on a per voyage basis. Transport work, in the form of distance travelled and cargo volumes carried, is also required [99], allowing for assessments of individual ships' $\mathrm{CO}_{2}$ performance (i.e. emissions relative to transport work). The IMO scheme just requires reporting of fuel consumption, ship capacity (deadweight), and distance travelled, but not cargoes carried [100], thus missing information on $\mathrm{CO}_{2}$ performance. It remains to be seen if or how IMO and EU systems can be harmonized [101].

For IMO, the MRV represents an advancement of the Ship Energy Efficiency Management Plan (SEEMP), which became mandatory for all ships in 2013. SEEMP was introduced in order to spur shipping companies to engage in energy efficiency measures. It requires all ships to carry a plan for energy management and was seen by IMO as an energy efficiency enhancement tool [102]. However, Poulsen and Johnson [55] indicate that the mandatory SEEMP had little practical impact on reporting behavior in shipping companies.

At a certain point in time, there was also discussion on inclusion of air pollutants in the EU MRV scheme, but this was dropped [103]. Air pollutants are not always linearly related to fuel consumption, but depend on ship-wide operational conditions. The EU MRV has been associated with controversy. In Lloyd's List, many ship-owners and the International Chamber of Shipping, representing more than half of the world's ship-owners, were concerned that the regional EU MRV, with the inclusion of transport work, would "distort" the market. Ship-owners argued that such a MRV would require them to reveal commercially sensitive information and create administrative burdens. Moreover, ship-owners felt that they were not always in control of transport work, and therefore this information should not be shared [104-107]. They were also critical against a regional EU measure, preferring global measures. The MRV controversy illustrates that a major share of the international ship-owner community does not embrace the idea of enhanced transparency on fuel consumption, and it remains to be seen how the MRV will affect environmental transparency in the market place. In their 2016 progress report [57 p. 8], the CCWG stated that they would "engage with regulatory standard-setting bodies (e.g., EU MRV)", but it is unclear what the outcome was. Ecorating schemes can potentially use MRV data, which could provide alignment between public and 
private initiatives, strengthen awareness about energy efficiency, and lead to improvements in ships' environmental performance. It remains to be seen how the MRVs and eco-ratings will interact.

\section{Discussion}

Do eco-ratings improve the environmental performance of ships or fail in their promises? Best practices with regard to eco-rating schemes' governance and design (universality, transparency, credibility and legitimacy) are not fulfilled, and therefore the full potential for improved environmental outcomes is most likely not achieved in shipping (Table 3). To the extent that shipping schemes do provide a basis for improvements in the environmental performance of ships, those are restricted to air emission abatement. 
Table 3. Evaluation of five eco-rating schemes in the shipping industry in terms of their design and governance

\begin{tabular}{|c|c|c|c|c|c|c|c|}
\hline Dimension & Criteria & Green Award & ESI & CCWG & CSI & EVDI & BetterFleet \\
\hline \multirow[t]{2}{*}{ Design } & Universality & $\begin{array}{l}\text { Partly overlapping } \\
\text { with the other } \\
\text { schemes }\end{array}$ & $\begin{array}{l}\text { Partly overlapping } \\
\text { with the other } \\
\text { schemes }\end{array}$ & $\begin{array}{l}\text { Partly } \\
\text { overlapping with } \\
\text { the other } \\
\text { schemes }\end{array}$ & $\begin{array}{l}\text { Partly overlapping } \\
\text { with the other } \\
\text { schemes }\end{array}$ & $\begin{array}{l}\text { Partly overlapping } \\
\text { with the other } \\
\text { schemes }\end{array}$ & $\begin{array}{l}\text { Partly overlapping with } \\
\text { the other schemes }\end{array}$ \\
\hline & Transparency & $\begin{array}{l}\text { A certification } \\
\text { scheme, but not a } \\
\text { tool for } \\
\text { environmental } \\
\text { benchmarking of } \\
\text { ships. A list of app. } \\
250 \text { certified } \\
\text { vessels is } \\
\text { published on the } \\
\text { foundation's web- } \\
\text { page. }\end{array}$ & $\begin{array}{l}\text { Includes app. 5,500 } \\
\text { vessels out of the } \\
\text { world fleet's 49,000 } \\
\text { vessels. Does not } \\
\text { allow for } \\
\text { benchmarking of } \\
\text { ships' } \\
\text { environmental } \\
\text { performance. Some } \\
\text { data sets are not } \\
\text { based on vessel } \\
\text { operations. }\end{array}$ & $\begin{array}{l}\text { High } \\
\text { transparency } \\
\text { concerning CO2 } \\
\text { emissions from } \\
\text { 3,300 out of } \\
\text { 5,200 container } \\
\text { ships, but data } \\
\text { sets are only } \\
\text { available for } \\
\text { cCWG members. }\end{array}$ & $\begin{array}{l}\text { CSI has the } \\
\text { broadest } \\
\text { definition of } \\
\text { environmental } \\
\text { performance } \\
\text { among the } \\
\text { schemes. } \\
\text { Relatively high } \\
\text { level of } \\
\text { transparency on } \\
\text { environmental } \\
\text { performance of } \\
\text { ships in the } \\
\text { database. Only for } \\
\text { CSI members and } \\
\text { number of vessels } \\
\text { included is } \\
\text { unknown. }\end{array}$ & $\begin{array}{l}\text { Apply to all ships in } \\
\text { the world fleet. } \\
\text { Does not allow for } \\
\text { benchmarking of } \\
\text { ships' operational } \\
\text { performance. Data } \\
\text { sets are based only } \\
\text { on ships in design } \\
\text { condition. }\end{array}$ & $\begin{array}{l}\text { High transparency } \\
\text { regarding CO2 emission } \\
\text { per transport work for } \\
\text { individual ships, but the } \\
\text { scheme is still under } \\
\text { development. Aiming } \\
\text { for covering of entire } \\
\text { world fleet. }\end{array}$ \\
\hline \multirow[t]{2}{*}{ Governance } & Legitimacy & $\begin{array}{l}\text { Incentive } \\
\text { providers and } \\
\text { certified ships } \\
\text { represent only a } \\
\text { minor share of the } \\
\text { port sector and } \\
\text { the world fleet, } \\
\text { respectively }\end{array}$ & $\begin{array}{l}\text { Adopted by app. } 50 \\
\text { ports around world- } \\
\text { wide, but relatively } \\
\text { little interest among } \\
\text { ship-owners. }\end{array}$ & $\begin{array}{l}\text { App. 85\% of } \\
\text { global ocean } \\
\text { container } \\
\text { capacity is } \\
\text { represented, but } \\
\text { on the shipper } \\
\text { side only } 22 \\
\text { large branded } \\
\text { cargo-owners } \\
\text { and freight } \\
\text { forwarders are } \\
\text { members, } \\
\text { representing } \\
\text { only a small } \\
\text { share of the } \\
\text { market. }\end{array}$ & $\begin{array}{l}\text { Despite a global } \\
\text { ambition, the CSI } \\
\text { remains largely a } \\
\text { Swedish initiative. }\end{array}$ & $\begin{array}{l}\text { Controversial } \\
\text { among ship-owners, } \\
\text { who have objected } \\
\text { against the EVDI } \\
\text { methodology. }\end{array}$ & $\begin{array}{l}\text { Introduced in } \\
\text { November } 2016 \text {, it is } \\
\text { too early to assess } \\
\text { legitimacy. }\end{array}$ \\
\hline & Credibility & $\begin{array}{l}\text { Certification of } \\
\text { ships is based on } \\
\text { audits onboard } \\
\text { and in shore } \\
\text { organizations } \\
\text { every three years. }\end{array}$ & $\begin{array}{l}\text { Data sets are based } \\
\text { on ship-owner self- } \\
\text { assessment, } \\
\text { although the WPCI } \\
\text { holds the right to } \\
\text { audit data. }\end{array}$ & $\begin{array}{l}\text { Some data sets } \\
\text { data are verified } \\
\text { by third parties, } \\
\text { but members are } \\
\text { also allowed to } \\
\text { submit data, } \\
\text { which has not } \\
\text { been verified. }\end{array}$ & $\begin{array}{l}\text { Third party } \\
\text { verification of data } \\
\text { by classification } \\
\text { societies. }\end{array}$ & $\begin{array}{l}\text { Credibility is } \\
\text { questionable, since } \\
\text { data sets are } \\
\text { derived from many } \\
\text { sources, some of } \\
\text { which are not third } \\
\text { party verified. }\end{array}$ & $\begin{array}{l}\text { Publicly available data } \\
\text { from satellites } \\
\text { concerning ship } \\
\text { movements have } \\
\text { relatively high } \\
\text { credibility. Anomalies in } \\
\text { data sets removed by a } \\
\text { commercial provider of } \\
\text { satellite data. }\end{array}$ \\
\hline
\end{tabular}


A couple of years ago, Wuisan et al. [23] saw a "promising" outlook for the Clean Shipping Project and called for a broadened collaboration between shipping companies, shippers, ports, and investors. This paper provides an update, indicating that the proposed collaboration has not materialized. Cargo-owners and ports have developed separate schemes and do not exercise joint or uniform environmental pressure on shipping companies. This study also resonates with Rahim et al.'s [28] critical assessment of $\mathrm{CO}_{2}$ disclosure in container shipping. Within the pages of Lloyd's List, no evidence suggests any widespread use of eco-ratings as differentiators in shipping markets. This also aligns with Van Leeuwen and van Koppen's [51] observations on "crisis-oriented" environmental strategies in shipping companies. No evidence in the shipping newspaper supports the positive relationship between environmental protection and corporate performance suggested by Lai et al. [22]. Credible environmental benchmarking with high legitimacy has not been achieved for the world fleet.

Wuisan et al. [23], Lister et al. [17], and Poulsen et al. [55], advocated for alignment of eco-rating schemes and regulation on corporate environmental disclosure to avoid conflicts, confusion, and unnecessary overlaps. The IMO and EU are introducing separate MRVs, and it remains to be seen if they will align in practice. A widespread ship-owner skepticism regarding the EU MRV system suggests that many ship-owners are still in doubt about the advantages of environmental benchmarking in the market place.

Within the energy efficiency literature, Agnolucci et al. [53 p. 183] concluded that "Any instrument facilitating the diffusion of information or reducing the costs of holding ship owners accountable to their energy efficiency claims will help increase the maximum amount that time charterers are will to pay for the increased energy efficiency and stimulate the uptake of energy efficiency investments." While the eco-ratings with focus on $\mathrm{CO}_{2}$ emissions do represent a step in this direction, their diffusion (perhaps with the exception of container shipping) is still insufficient to provide credible energy efficiency information in the market place.

In their study of ecolabels for airlines, Baumeister and Onkila [46] focused entirely on fuel consumption and $\mathrm{CO}_{2}$ emissions as an environmental performance metric. Shipping has a multifaceted environmental footprint, but eco-rating schemes focus predominantly on air emissions, which are directly related to ship operations. Accidental challenges (invasive species, oil spills, interaction with marine mammals) and end-of-life-cycle problems (recycling) are largely neglected by shipping schemes.

This study adds two important insights to the private environmental governance literature, which has neglected mature service industries with global operations such as shipping. Firstly, it shows that some of the concerns about eco-ratings' environmental effectiveness identified elsewhere also have relevance for service industries. If schemes do not provide a high level of transparency, and achieve strong credibility and legitimacy, the achievement of improved environmental outcomes will also be hampered in services. Secondly, maturity - as reflected by standardized technologies - does not guarantee that improved environmental outcomes occur when eco-ratings are introduced. Improved environmental outcomes in mature industries still depend on the close collaboration between all relevant stakeholders. As long as ports and cargo-owners pull in different directions, financiers are 
not involved, and public and private transparency initiatives are not fully aligned, the full potential for improvements in the environmental performance of ships is not likely to be achieved.

\section{Conclusion}

The environmental effectiveness of eco-rating schemes, which provide environmental performance information to the market place, has been a matter of debate since the early 1990s. Ideally, ecoratings or eco-labels provide buyers and sellers with relevant environmental performance information, and incentivize improvements. However, companies might use them to deflect regulation or create information overload in the marketplace, in which case improvements will fail to materialize. This paper extends the private environmental governance literature into the shipping industry, a mature service industry with global operations, which has largely been neglected. Shipping faces several environmental challenges - including climate changes, air pollution, invasive species, and recycling - and has witnessed the emergence of several eco-rating schemes since the early 2000s. The paper evaluates if the shipping schemes lead to improvements in the environmental performance of ships.

A relatively late adopter of eco-ratings, the shipping industry can potentially leverage experiences from other industries, pertaining to scheme design and governance. The literature shows that there should be only one scheme (universality), and it should provide third party verified data for benchmarking of environmental performance (credibility and transparency). Finally, in order to achieve improved environmental outcomes, the scheme should enjoy widespread stakeholder support (legitimacy). However, shipping schemes largely fall short of the best practices, and this hampers efforts to improve the environmental performance of ships.

No shipping scheme has achieved universal recognition. Instead several, partly overlapping schemes exist. Key stakeholders, cargo-owners and ports, are concerned with different challenges, and financiers are not involved. Ports focus on local air pollution, while some container shipping cargoowners are mainly addressing global climate changes, and therefore pull in different directions. There is no evidence to suggest that many ship-owners use eco-ratings to differentiate their services, and some schemes lack credibility because they are not verified by third parties. Moreover, some schemes do not allow for benchmarking of ships' operational performance, as they are mainly concerned with ships in design condition. Some labels have been associated with considerable controversy and lack legitimacy in the ship owner community. Civil society engagement from NGOs, which is important for legitimacy and environmental effectiveness, remains very low.

Both the IMO and EU are introducing new regulation, requiring shipping companies to publicize fuel consumption and $\mathrm{CO}_{2}$ emissions data, indicating that policy makers are dissatisfied with private achievements. It remains to be seen if eco-rating schemes and MRVs can align in the effort to achieve improved environmental outcomes.

In adding to the private environmental governance literature, this study shows how common concerns about eco-rating schemes' effectiveness also have relevance in the context of services. Improved environmental outcomes are not guaranteed when eco-rating schemes are introduced. This requires alignment of private and public initiatives and close collaboration between all relevant stakeholders. 
This study has important policy implications in pointing out circumstances, which could improve the environmental performance of ships. Firstly, coordination of private initiatives among ports and cargo owners could avoid duplication, enhance environmental transparency, and strengthen ecorating scheme legitimacy. Secondly, alignment between public and private transparency initiatives could enhance transparency. Thirdly, environmental challenges unrelated to ships' air emissions (such as invasive species, recycling, and interaction with marine mammals) require further policy attention because they are neglected by the private eco-rating schemes.

The topic of corporate environmental disclosure and environmental performance deserves further study in the context of international shipping. The interaction between public and private initiatives and the environmental effects of the upcoming MRV systems represent a promising area for further research. Longitudinal studies of shipping companies and shipping segments would be relevant to answer the question of how MRV and eco-ratings affect individual companies and market dynamics more generally. Such studies promise to shed new light on the circumstances, under which improved environmental outcomes can occur not only on the ship level, but also more broadly for the shipping industry at large.

\section{References}

[1] P.M. Mukherjee, M. Brownrigg, Farthing on International Shipping, 3rd Ed., Springer, Heildelberg, 2013.

[2] T.W.P. Smith, J.P. Jalkanen, B.A. Anderson, J.J. Corbett, J. Faber, S. Hanayama, E. O'Keeffe, S. Parker, L. Johansson, L. Aldous, C. Raucci, M. Traut, S. Ettinger, D. Nelissen, D.S. Lee, S. Ng, A. Agrawal, J.J. Winebrake, M. Hoen, S. Chesworth, A. Pandey, Third IMO GHG Study, International Maritime Organization, London, 2014.

[3] R. Asariotis, H. Benamara, Maritime Transport and the Climate Change Challenge, Earthscan, London, 2012.

[4] C. Wang, J.J. Corbett, J.J. Winebrake, Cost-effectiveness of reducing sulfur emissions from ships, Environ. Sci. Technol. 41 (2007) 8233-8239.

[5] E. Tzannatos, Ship emissions and their externalities for the port of Piraeus - Greece, Atmos. Environ. 44 (2010) 400-407.

[6] J. Brandt, J.D. Silver, J.H. Christensen, M.S. Andersen, J.H. Bønløkke, T. Sigsgaard, C. Geels, A. Gross, A.B. Hansen, K.M. Hansen, G.B. Hedegaard, E. Kaas, L.M. Frohn, Contribution from the ten major emission sectors in Europe and Denmark to the health-cost externalities of air pollution using the EVA model system-an integrated modelling approach, Atmos. Chem. Phys. 13 (2013) 7725-7746. doi:10.5194/acp-13-7725-2013.

[7] M. Viana, P. Hammingh, A. Colette, X. Querol, B. Degraeuwe, I. de Vlieger, J. van Aardenne, Impact of maritime transport emissions on coastal air quality in Europe, Atmos. Environ. 90 (2014) 96-105. doi:10.1016/j.atmosenv.2014.03.046.

[8] S.D. Chatzinikolaou, N.P. Ventikos, Holistic framework for studying ship air emissions in a life cycle perspective, Ocean Eng. 110 (2015) 113-122. doi:10.1016/j.oceaneng.2015.05.042. 
[9] N. Bax, J.T. Carlton, A. Mathews-Amos, R.L. Haedrich, F.G. Howarth, J.E. Purcell, A. Rieser, A. Gray, The Control of Biological Invasions in the World's Oceans, Conserv. Biol. 15 (2001) 1234-1246. doi:10.1111/j.1523-1739.2001.99487.x.

[10] J.L. Molnar, R.L. Gamboa, C. Revenga, M.D. Spalding, Assessing the global threat of invasive species to marine biodiversity, Front. Ecol. Environ. 6 (2008) 485-492. doi:10.1890/070064.

[11] C. Dibacco, D.B. Humphrey, L.E. Nasmith, C.D. Levings, Ballast water transport of nonindigenous zooplankton to Canadian ports, ICES J. Mar. Sci. 69 (2012) 483-491.

[12] E. Briski, S. Ghabooli, S.A. Bailey, H.J. Maclsaac, Invasion risk posed by macroinvertebrates transported in ships' ballast tanks, Biol. Invasions. 14 (2012) 1843-1850. doi:10.1007/s10530-0120194-0.

[13] F.T. Chan, S.A. Bailey, C.J. Wiley, H.J. Maclsaac, Relative risk assessment for ballast-mediated invasions at Canadian Arctic ports, Biol. Invasions. 15 (2013) 295-308. doi:10.1007/s10530-0120284-z.

[14] H. Slabbekoorn, N. Bouton, I. van Opzeeland, A. Coers, C. ten Cate, A.N. Popper, A noisy spring: The impact of globally rising underwater sound levels on fish, Trends Ecol. Evol. 25 (2010) 419-427. doi:10.1016/j.tree.2010.04.005.

[15] A.M. Hiremath, A.K. Tilwankar, S.R. Asolekar, Significant steps in ship recycling vis-a-vis wastes generated in a cluster of yards in Alang: A case study, J. Clean. Prod. 87 (2015) 520-532. doi:10.1016/j.jclepro.2014.09.031.

[16] A.S.M. Vanderlaan, C.T. Taggart, Vessel collisions with whales: The probability of lethal injury based on vessel speed, Mar. Mammal Sci. 23 (2007) 144-156. doi:10.1111/j.17487692.2006.00098.x.

[17] J. Lister, R.T. Poulsen, S. Ponte, Orchestrating transnational environmental governance in maritime shipping, Glob. Environ. Chang. 34 (2015) 185-195. doi:10.1016/j.gloenvcha.2015.06.011.

[18] K. Anderson, A. Bows, Executing a Scharnow turn: reconciling shipping emissions with international commitments on climate change, Carbon Manag. 3 (2012) 615-628.

doi:10.4155/cmt.12.63.

[19] A. Bows-Larkin, All adrift: aviation, shipping, and climate change policy, Clim. Policy. 15 (2015) 681-702. doi:10.1080/14693062.2014.965125.

[20] C. Walsh, S. Mander, A. Larkin, Charting a low carbon future for shipping: A UK perspective, Mar. Policy. 82 (2017) 32-40. doi:10.1016/j.marpol.2017.04.019.

[21] E.R. DeSombre, Flagging Standards: Globalization and Environmental, Safety, and Labor Regulations at Sea, MIT Press Books, Cambridge MA, 2006.

http://ideas.repec.org/b/mtp/titles/0262541904.html. 
[22] K.-H. Lai, V.Y.H. Lun, C.W.Y. Wong, T.C.E. Cheng, Green shipping practices in the shipping industry: Conceptualization, adoption, and implications, Resour. Conserv. Recycl. 55 (2011) 631-638. doi:10.1016/j.resconrec.2010.12.004.

[23] L. Wuisan, J. van Leeuwen, C.S.A. (Kris) van Koppen, Greening international shipping through private governance: A case study of the Clean Shipping Project, Mar. Policy. 36 (2012) 165-173.

[24] I. Rojon, C. Dieperink, Blowin' in the wind? Drivers and barriers for the uptake of wind propulsion in international shipping, Energy Policy. 67 (2014) 394-402.

doi:10.1016/j.enpol.2013.12.014.

[25] A. McKinnon, The possible influence of the shipper on carbon emissions from deep-sea container supply chains: An empirical analysis, Marit. Econ. Logist. 16 (2014) 1-19. doi:10.1057/mel.2013.25.

[26] N. Rehmatulla, T. Smith, Barriers to energy efficient and low carbon shipping, Ocean Eng. 110 (2015) 102-112. doi:10.1016/j.oceaneng.2015.09.030.

[27] R.T. Poulsen, S. Ponte, J. Lister, Buyer-driven greening? Cargo-owners and environmental upgrading in maritime industry, Geoforum. 68 (2016) 57-68.

[28] M.M. Rahim, M.T. Islam, S. Kuruppu, Regulating global shipping corporations' accountability for reducing greenhouse gas emissions in the seas, Mar. Policy. 69 (2016) 159-170. doi:10.1016/j.marpol.2016.04.018.

[29] R.R. Hermann, K. Wigger, Eco-Innovation Drivers in Value-Creating Networks: A Case Study of Ship Retrofitting Services, Sustainability. 9 (2017) 733.

[30] S. Mander, Slow steaming and a new dawn for wind propulsion: A multi-level analysis of two low carbon shipping transitions, Mar. Policy. 75 (2017) 210-216.

[31] R.R. Hermann, Drivers for environmental technologies selection in the shipping industry: A case study of the North European Sulphur Emission Control Area, Int. J. Environ. Technol. Manag. In Press (2017).

[32] SSI, Rating schemes-Guidance for users, dated September 2013. Sustainable Shipping Initiative, (2013). http://ssi.brenock.com/docs/SSIguidanceforusers.pdf (accessed November 2, 2016).

[33] L.H. Guldbrandsen, Mark of sustainability? Challenges for Fishery and Forestry Eco-labeling, Environ. Sci. Policy Sustain. Dev. 47 (2005) 8-23.

[34] L.H. Guldbrandsen, The emergence and effectiveness of the Marine Stewardship Council, Mar. Policy. 33 (2009) 654-660. doi:10.1016/j.marpol.2009.01.002.

[35] M.G. Arnold, K. Hockerts, The greening dutchman: Philips' process of green flagging to drive sustainable innovations, Bus. Strateg. Environ. 20 (2011) 394-407.

[36] P.H. Howard, P. Allen, Beyond Organic and Fair Trade? An Analysis of Ecolabel Preferences in the United States, Rural Sociol. 75 (2010) 244-269. doi:10.1111/j.1549-0831.2009.00009.x. 
[37] S. Eden, The work of environmental governance networks: Traceability, credibility and certification by the Forest Stewardship Council, Geoforum. 40 (2009) 383-394.

doi:10.1016/j.geoforum.2008.01.001.

[38] D.H. Schepers, Challenges to legitimacy at the forest Stewardship council, J. Bus. Ethics. 92 (2010) 279-290. doi:10.1007/s10551-009-0154-5.

[39] K.G. Wingate, P.N. McFarlane, Chain of custody and eco-labelling of forest products: a review of the requirements of the major forest certification schemes, Int. For. Rev. 7 (2005) 342347. doi:10.1505/ifor.2005.7.4.342.

[40] P. Dauvergne, J. Lister, The Prospects and Limits of Eco-Consumerism: Shopping Our Way to Less Deforestation?, Organ. Environ. 23 (2010) 132-154. doi:10.1177/1086026610368370.

[41] D'Amico, A. Armani, D. Gianfaldoni, A. Guidi, New provisions for the labelling of fishery and aquaculture products: Difficulties in the implementation of regulation(EU) n. 1379/2013, Mar. Policy. 71 (2016) 147-156.

[42] M. Stopford, Maritime Economics, 3rd ed., Routledge, London, 2009.

[43] N. Wijnolst, T. Wergeland, Shipping Innovation, Delft University Press, Delft, 2009. doi:10.1007/s11408-013-0209-6.

[44] S. Ponte, Greener than Thou: The Political Economy of Fish Ecolabeling and Its Local Manifestations in South Africa, World Dev. 36 (2008) 159-175. doi:10.1016/j.worlddev.2007.02.014.

[45] G. Auld, L.H. Gulbrandsen, C.L. McDermott, Certification Schemes and the Impacts on Forests and Forestry, Annu. Rev. Environ. Resour. 33 (2008) 187-211. doi:10.1146/annurev.environ.33.013007.103754.

[46] S. Baumeister, T. Onkila, An eco-label for the airline industry?, J. Clean. Prod. 142 (Part (2017) 1368-1376.

[47] S. Moog, A. Spicer, S. Böhm, The Politics of Multi-Stakeholder Initiatives: The Crisis of the Forest Stewardship Council, J. Bus. Ethics. 128 (2014) 469-493. doi:10.1007/s10551-013-2033-3.

[48] M. Thrane, F. Ziegler, U. Sonesson, Eco-labelling of wild-caught seafood products, J. Clean. Prod. 17 (2009) 416-423. doi:10.1016/j.jclepro.2008.08.007.

[49] M.J. Kaiser, G. Edwards-Jones, The role of ecolabeling in fisheries management and conservation, Conserv. Biol. 20 (2006) 392-398. doi:10.1111/j.1523-1739.2006.00319.x.

[50] C. Christian, D. Ainley, M. Bailey, P. Dayton, J. Hocevar, M. LeVine, J. Nikoloyuk, C. Nouvian, E. Velarde, R. Werner, J. Jacquet, A review of formal objections to Marine Stewardship Council fisheries certifications, Biol. Conserv. 161 (2013) 10-17. doi:10.1016/j.biocon.2013.01.002.

[51] J. van Leeuwen, C.S.A. van Koppen, Moving Sustainable Shipping Forward : The Potential of Market-based Mechanisms to Reduce CO2 Emissions from Shipping, J. Sustain. Mobil. 3 (2016) 4266. 
[52] D.G. Schniederjans, C.M. Starkey, Intention and willingness to pay for green freight transportation: An empirical examination, Transp. Res. Part D Transp. Environ. 31 (2014) 116-125. doi:10.1016/j.trd.2014.05.024.

[53] P. Agnolucci, T. Smith, N. Rehmatulla, Energy efficiency and time charter rates: Energy efficiency savings recovered by ship owners in the Panamax market, Transp. Res. Part A Policy Pract. 66 (2014) 173-184.

[54] R. Adland, H. Alger, J. Banyte, H. Jia, Does fuel efficiency pay? Evidence from the drybulk timecharter market revisited, Transp. Res. Part A. 95 (2017) 1-12.

[55] T. Poulsen, H. Johnson, The logic of business vs . the logic of energy management practice : understanding the choices and effects of energy consumption monitoring systems in shipping companies, J. Clean. Prod. 112 (Part (2016) 3785-3797. doi:10.1016/j.jclepro.2015.08.032.

[56] SSI, Ratings and Schemes, (2016). http://ssi.brenock.com/scheme/search (accessed November 2, 2016).

[57] CCWG, Collaborative Progress; Clean Cargo Working Group 2016 Progress Report, (2016). https://www.bsr.org/reports/Clean_Cargo_Progress_Report_2016.pdf (accessed July 6, 2017).

[58] Rightship, GHG Emissions Rating, (2017). https://site.rightship.com/ghg-rating/ (accessed July 7, 2017).

[59] IMO, EEDI - rational, safe and effective, (2017).

http://www.imo.org/en/MediaCentre/HotTopics/GHG/Pages/EEDI.aspx (accessed July 7, 2017).

[60] CCWG, Clean Cargo Working Group Carbon Emissions Accounting Methodology, (2015). https://www.bsr.org/reports/BSR_CCWG_Carbon_Emissions_Methodology_2015.pdf (accessed July 6, 2017).

[61] Clean Shipping Index, Verification Guidelines for Vessels and Shipping Companies, (2015). https://app.cleanshippingindex.com/docs/VERIFICATION\%20GUIDELINES\%20v\%204\%20April\%20201 5.pdf (accessed July 6, 2017).

[62] Clean Shipping Index, Methodology and Reporting Guidelines, (2017). http://cleanshippingindex.com/wp-content/uploads/2017/06/Methodology-and-ReportingGuidelines.pdf (accessed July 7, 2017).

[63] WPCl, About us, (2017). http://www.environmentalshipindex.org/Public/Home (accessed July 6, 2017).

[64] ESI, Environmental Ship Index-Formulas, (2017). http://www.environmentalshipindex.org/Public/Home/ESIFormulas (accessed July 7, 2017).

[65] Green Award, The pride of the oceans, (2017). http://www.greenaward.org/greenaward/ (accessed July 6, 2017).

[66] Lloyd's List, Intertanko slams green bid, Lloyd's List. 5 March 1993. (1993). 
[67] Green Award, Green Award, Requirements for Tankers, (2017).

http://www.greenaward.org/greenaward/file.php?id=1167\&hash=a4cc8441d01c15e424569bc9ab8 338d1 (accessed July 6, 2017).

[68] Green Award, All Certificate Holders, (2017). http://www.greenaward.org/greenaward/13all-seagoing-ships.html (accessed July 6, 2017).

[69] S. Brynolf, F. Baldi, H. Johnson, Energy Efficiency and Fuel Changes to Reduce Environmental Impacts, in: K. Andersson, S. Brynolf, J.F. Lindgren, M. Wilewska-Bien (Eds.), Shipp. Environ. Improv. Environ. Perform. Mar. Transp., Springer Berlin Heidelberg, Berlin, Heidelberg, 2016: pp. 295-339. doi:10.1007/978-3-662-49045-7_10.

[70] A. Adamopoulos, Ballast Water Convention Extension Looms Large, Lloyd's List. 3 July 2017. (2017).

[71] A. Adamopoulos, Shipping's environmental commitments head for crunch point, Lloyd's List. 3 July 2017. (2017).

[72] F. Demaria, Shipbreaking at Alang-Sosiya (India): An ecological distribution conflict, Ecol. Econ. 70 (2010) 250-260. doi:10.1016/j.ecolecon.2010.09.006.

[73] IMO, IMO Ballast Water Management, Ballast Water Manag. (2017). http://www.imo.org/en/OurWork/Environment/BallastWaterManagement/Pages/Default.aspx (accessed July 6, 2017).

[74] J.I. Alcaidea, F. Piniella, E. Rodríguez-Díaza, The "Mirror Flags": Ship registration in globalised ship breaking industry, Transp. Res. Part D Transp. Environ. 48 (2016) 378-392.

doi:10.1016/j.trd.2016.08.020.

[75] ESI, Environmental Ship Index, (2017).

http://www.environmentalshipindex.org/Public/Home (accessed July 6, 2017).

[76] Green Award, Green Award Certification Procedure, (2017).

http://www.greenaward.org/greenaward/347-procedure-.html (accessed July 6, 2017).

[77] UNCTAD, Review of Maritime Transport 2016, Geneve, 2016.

http://unctad.org/en/PublicationsLibrary/rmt2016_en.pdf.

[78] C. Eason, Ports to use controversial EVDI to discount their harbour dues, Lloyd's List. 4 Feb. 2013. (2013).

[79] C. Eason, Shipping to get industry-wide tool to measure existing ship efficiency, Lloyd's List. 25 January 2013. (2013).

[80] C. Eason, Intercargo attacks "simplistic and inaccurate" Rightship green ranking, Lloyd's List. 2 Oct. 2012. (2012).

[81] C. Eason, Call to reject environmental performance indicators, Lloyd's List. 8 Oct. 2012. (2012). 
[82] T. Leander, Measure of truth, Lloyd's List. 4 December 2012. (2012).

[83] Clean Shipping Index, CSI-Membership information, (2017).

http://cleanshippingindex.com/members/ (accessed June 30, 2017).

[84] C. Eason, Clean Shipping Index launches commercial offering, Lloyd's List. 9 Feb. 2011. (2011).

[85] Lloyd's List, Some like it hot, Lloyd's List. 28 Sept. 2012. (2012).

[86] R. Hailey, Clean Shipping Index seeks more users, Lloyd's List. 18 May 2012. (2012).

[87] C. Eason, Gothenburg to offer $30 \%$ off port dues for gas-fueled ships, Lloyd's List. 30 June 2014. (2014).

[88] W.Z. Than, Anthony Veder secures first certified "sustainable" shipping loan, Lloyd's List. 25 January 2016. (2016).

[89] ESI, List of Participating Incentives Providers, Environ. Shipp. Index. (2017). http://www.environmentalshipindex.org/Public/PortIP (accessed July 6, 2017).

[90] ESI, List of Participating Ships, Environ. Shipp. Index. (2017).

http://www.environmentalshipindex.org/Public/Ships (accessed July 6, 2017).

[91] J. Baker, Antwerp offers green ship discounts, Lloyd's List. 19 May 2015. (2015).

[92] Lloyd's List, Port of Rotterdam adds fresh incentive for ships to bunker LNG, Lloyd's List. 17 December 2015. (2015).

[93] Lloyd's List, Rotterdam raises port tariffs by 0.3\%, Lloyd's List. 5 December 2016. (2016).

[94] Green Award, Green Awards, Efforts versus benefits, (2010).

http://www.greenaward.org/greenaward/file.php?id=163\&hash=c227d89e9748d5a504bdaa1f32cf4 e75 (accessed July 6, 2017).

[95] Rightship, Rightship Shipowners, (2017). https://site.rightship.com/ghg-rating/shipowners/ (accessed July 6, 2017).

[96] E. Yep, Is this the tipping point for LNG fuel?, Lloyd's List. 2 May 2017. (2017).

[97] Rightship, Rightship financial institutions, (2017). https://site.rightship.com/ghgrating/financial-institutions/ (accessed July 6, 2017).

[98] Clean Shipping Index, What's in it for me? Investors, Clean Shipp. Index. (2017). https://site.rightship.com/ghg-rating/financial-institutions/ (accessed July 6, 2017).

[99] European Commission, Expert groups on monitoring, reporting and verification of shipping emissions, (2017). https://ec.europa.eu/clima/events/articles/0108_en (accessed July 6, 2017). 
[100] IMO, Data collection system on fuel oil consumption of ships, (2017).

http://www.imo.org/en/OurWork/Environment/PollutionPrevention/AirPollution/Pages/Data-

Collection-System.aspx (accessed July 6, 2017).

[101] A. Adamopoulos, IMO-EU MRV alignment facing minimum five-year delay, Lloyd's List. 13 January 2017. (2017).

[102] IMO, IMO Energy Efficiency Measures, (2017).

http://www.imo.org/en/OurWork/Environment/PollutionPrevention/AirPollution/Pages/Technicaland-Operational-Measures.aspx (accessed July 6, 2017).

[103] C. Eason, Brussels politicians press for reporting of ships' NOx emissions, Lloyd's List. 24 January 2014. (2014).

[104] C. Eason, Recent developments in Brussels' carbon emission reporting scheme spark shipowner concern, Lloyd's List. 27 November. 2014. (2014).

[105] M. Grey, The tyranny of data, Lloyd's List. 15 December 2014. (2014).

[106] G. Howard, IMO mandatory CO2 data collection system set for October adoption, Lloyd's List. 22 April 2016. (2016).

[107] G. Howard, ICS lobbying EU to blunt regional MRV regulation, Lloyd's List. 6 June 2016. (2016).

[108] ISO. How ISO standards help: Environmental labels and declarations. ISO: Geneva, 2012.

[109] K. Kuganeswaran, Cruiseships fare poorly in pollution rankings, Lloyd's List, 5 September 2017. (2017).

[110] S. Pettit, P. Wells, J. Haider, W. Abouarghoub, Revisiting history: Can shipping achieve a second socio-technical transition for carbon emissions reduction?, Transp. Res. Part D Transp. Environ. (2017). doi:10.1016/j.trd.2017.05.001.

[111] G. Hon, T. Smith, E. Hauerhof, BetterFleet: Data and Method, http://shippingefficiency.org/sites/shippingefficiency.org/files/BetterFleet-Methodology.pdf, accessed on October 2, 2017.

[112] Better Fleet, http://shippingefficiency.org/betterfleet, accessed on October 2, 2017. 